\title{
'Science Wars' blamed for loss of post
}

[WASHINGTON] Social scientists at the Institute for Advanced Study at Princeton, New Jersey, have decided to stop trying to build up a research capability in 'science studies' after failing to secure the appointment of a historian of science from Princeton University to a faculty position.

The decision has been taken against a background of intense dispute with natural scientists at the institute, who had opposed the appointment of the historian - Norton Wise - because, the social scientists allege, of their hostility to science studies as an academic discipline.

The Institute for Advanced Study is a small but distinguished research school, unconnected to the adjacent Princeton University. Wise's appointment was halted by the institute director, Phillip Griffiths, after a specially appointed panel had split 4:2 in Wise's favour.

The panel consisted of three outside experts in science studies and representatives of each of the institute's other three schools - history, mathematics and natural sciences. It was set up after a similar row six years ago, when the French sociologist Bruno Latour was rejected for the same slot.

In the interim, the institute had agreed to appoint Peter Galison, a historian of science at Harvard University. But Galison eventually turned down the offer because his wife was unable to find a suitable job nearby. The school of social science will now return a $\$ 500,000$ grant, intended to fund the position, to the Henry Luce Foundation.

After the panel vote, Griffiths asked for outside advice from, among others, the physicists Steven Weinberg and Gerald
Holton. Weinberg had publicly clashed with Wise in the increasingly acrimonious series of arguments about the study of science, sometimes known as the 'Science Wars' (see Briefing, page 331).

Social scientists at the institute describe this exercise as 'a fishing expedition' deliberately mounted to gather criticism of Wise.

Officials at the institute say that the final decision, first reported in the Chronicle of Higher Education, was based purely on Wise's merits as a scholar. Griffiths says: "This was simply an issue of the appointment of an individual - it was not a 'Science Wars' issue at all."

Griffiths declines to discuss these merits specifically, and Ed Witten, the string theorist and one of the panel members who voted against Wise, refuses to comment on the decision. Glen Bowersock, a classical historian and the second 'no', says that it was "a judgement call based on quality", not on Wise's field of study.

According to one outside academic, Wise's publishing record was felt to be weak, both qualitatively and quantitatively. "The scientists are not stupid and they are not illwilled," the academic says. "What they'd like to have is quality."

But Joan Scott, one of the three current faculty members in the social science school, accuses Wise's detractors of "taking a McCarthyist approach" in the run-up to the decision, and calls Griffiths' denial "absurd".

She argues that Wise was excluded because of his position in the Science Wars debate. "We are now abandoning our attempt to represent science studies at the institute," she says. "We know who the top

\section{IMAGE \\ UNAVAILABLE \\ FOR COPYRIGHT REASONS}

Wise: supporters say failed appointment was due to hostility to science studies as a discipline.

people are in the field, and we don't see how we can come up with somebody that will be acceptable on all of the grounds that the institute requires. We've exhausted all the possibilities."

Clifford Geertz, an anthropologist and member of the social science faculty, also refuses to believe that the decision about Wise was based solely on merit. "Wise is a figure of great standing in history of science, as letters from his peers demonstrated," he says, adding that a group of "very determined people" on the natural science faculty had worked to block the appointment.

Wise admits that he has not published much in recent years, saying he has been preoccupied with improving the history of science programme at Princeton University. He says his main concern is that his non-appointment will discourage young historians of science who are already alarmed by what he terms "direct threats" that have been made by some scientists to regain control over science studies.

ColinMacilwain

\section{Row over subsidies could delay EU Framework programme}

[MUNICH] Political disagreement between member states of the European Union threatens to delay the start of the EU's fifth Framework research programme (FP5), due to begin in 1999, by disrupting the programme's approval procedure.

At a meeting of the EU council of research ministers last week, Spain refused to allow a formal decision to be reached on draft proposals for FP5 that have been drawn up by the European Commission until the commission's overall budget beyond 1999 has been agreed.

Spain is concerned that after 1999 the EU's subsidies to its poorer regions, known as 'cohesion funds' and from which Spain benefits significantly, may be severely cut. Its concern is said to be shared by Ireland, Portugal and Greece.

These countries could block progress on FP5 as a way of putting pressure on other EU members to reverse the cuts. As a result, many national delegations to the council fear that the current, fourth Framework programme may have to be extended by a year to fill the funding gap. The proposals for FP5 require the unanimous approval of the council.

Although Spain's reservations meant that no formal decisions could be taken, last week's council meeting agreed that the scope of the commission's FP5 proposal should be slightly expanded. Officials say they had kept the scope deliberately narrow to ensure a more targeted use of funds.

The commission had proposed three broad thematic programmes, including 16 so-called 'key actions' (see Nature 386, 527; 1997). A broad consensus was reached last week that two of the thematic programmes should be split into more manageable components. That would mean separating life sciences from environmental issues, and separating energy from a general industrial technologies' package, creating two new thematic programmes.

Several countries, including Germany, France and the United Kingdom, also pressed for a further thematic programme on transport, but this was rejected by other member states.

The council of research ministers also called on the commission to provide a clearer definition of its proposed role for basic research in FP5. This is not explicitly mentioned in the proposal. Most delegations want assurance that basic research would be funded only in limited and clearly defined areas such as neuroscience or nanotechnology.

In a statement, the council declared its resolve to "make every effort" to enable FP5 to start on time.

Alison Abbott 